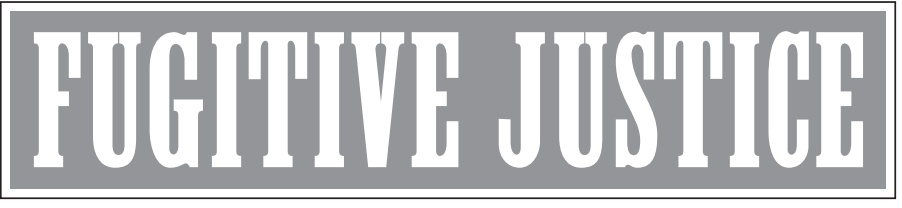





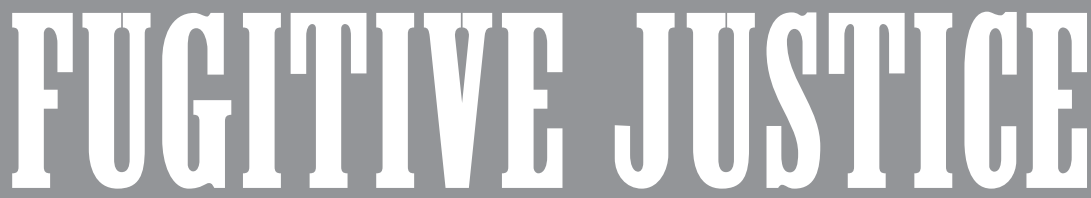

\section{Runaways, Rescuers, and Slavery on Trial}

\section{STEVEN LUBET}

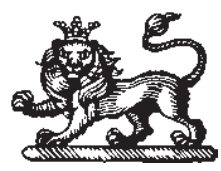

The Belknap Press of Harvard University Press

Cambridge, Massachusetts $\bullet$ London, England 2010 
Copyright (c) 2010 Steven Lubet

All rights reserved

Printed in the United States of America

Library of Congress Cataloging-in-Publication Data

Lubet, Steven.

Fugitive justice : runaways, rescuers, and slavery on trial / Steven Lubet.

p. $\mathrm{cm}$.

Includes bibliographical references and index.

ISBN 978-0-674-04704-4 (alk. paper)

1. Trials (Treason) - United States. 2. United States. Fugitive slave law (1850). 3. Fugitive slaves-Legal status, laws, etc.-United States. 4. Slavery-Law and legislation-United States. 5. Antislavery movements-United States. 6. Loring, Edward G. (Edward Greely), 1802-189o. I. Title.

KF221.P6L83 2010

342.7308'7-dc22 
To Sarah Nomi 
